\title{
Confirmatory factor analysis of head of department's functional competencies development: a case study in the secondary schools inThailand
}

\author{
Análisis factorial confirmatorio del desarrollo de las competencias funcionales del jefe de \\ departamento: un estudio de caso en las escuelas secundarias de Tailandia
}

\author{
AEBSAPAP, Teerasak ${ }^{1}$ \\ PARIYAPORN, Tungkunanan ${ }^{2}$ \\ BOONCHAN, Sisan ${ }^{3}$
}

\begin{abstract}
Functional competencies of Head of Department has been paid attention to because for a school in Thailand, the head of each department, is very important. However, the issue is the appointment of a teacher who does not have any prior proper training before. This may cause such a teacher to have incomplete functional competencies. Therefore, it is necessary to develop the functional competencies of the Head of Department. This research focuses on the components of the functional competencies of the Head of Department of secondary schools under the Office of the Basic Education Commission. As for this study, from the review on a great number of related literature, it can be granted that functional competencies of the Head of Department of secondary schools under the Office of the Basic Education Commission can be grouped as follows: 1) Intellectual Leadership 2) Quality Management 3) Educational Innovation and Information Technology 4) Professionalism Development 5) Curriculum, Measurement and Evaluation of Learning 6) Learning Organization and 7) Professional Ethic. These seven dimensions are then examined using Confirmatory Factor Analysis, which shows the congruence with the empirical studies.

Key words: head of department, functional competencies, confirmatory Factor Analysis

\section{Resumen}

Se ha prestado atención a las competencias funcionales del jefe de departamento porque para una escuela en Tailandia, el jefe de cada departamento es muy importante. Sin embargo, el problema es el nombramiento de un profesor que no haya tenido una formación adecuada previa. Esto puede hacer que dicho profesor tenga competencias funcionales incompletas. Por tanto, es necesario desarrollar las competencias funcionales del Jefe de Departamento. Esta investigación se centra en los componentes de las competencias funcionales del Jefe de Departamento de escuelas secundarias dependiente de la Oficina de la Comisión de Educación Básica. En cuanto a este estudio, de la revisión de una gran cantidad de literatura relacionada, se puede asegurar que las competencias funcionales del Jefe de Departamento de Secundaria dependiente de la Oficina de la Comisión de Educación Básica se pueden agrupar de la siguiente manera: 1) Liderazgo Intelectual 2 ) Gestión de la calidad 3) Innovación educativa y tecnologías de la información 4) Desarrollo del profesionalismo 5) Plan de estudios, medición y evaluación del
\end{abstract}

\footnotetext{
${ }^{1}$ Educational Administration. Faculty of Industrial Education and Technology. King Mongkut's Institute of Technology Ladkrabang. bellteerasak8088@gmail.com

${ }^{2}$ Educational Administration. Faculty of Industrial Education and Technology. King Mongkut's Institute of Technology Ladkrabang. pariyaporn.tu@kmitl.ac.th

${ }^{3}$ Educational Administration. Faculty of Industrial Education and Technology. King Mongkut's Institute of Technology Ladkrabang. kiboonch@kmitl.ac.th
} 
aprendizaje 6) Organización del aprendizaje y 7) Ética profesional. Estas siete dimensiones se examinan luego mediante el Análisis Factorial Confirmatorio, que muestra la congruencia con los estudios empíricos.

Palabras clave: jefe de departamento, competencias funcionales, análisis factorial confirmatorio

\section{Introduction}

The challenges that constitute the dynamism of the world in $21^{\text {st }}$ Century include external/international pressures such as changes in the sociology-economy contexts of the world due to digital revolution, the operation to achieve Sustainable Development Goals for Year 2030 (SDGs 2030) that Thailand has ratified, impacts from the membership of ASEAN Community and the need for skilled labors in $21^{\text {st }}$ Century, and internal/domestic pressures such as the change in the structure of populations that has caused the country to completely become a society of the elder in the night future, the economic growth of the country that has caused rapid destruction and degradation of natural resources, and education system that is facing with several problems, including the quality of Thai citizens in all age ranges, quality and standards of education in all levels, weaknesses of the system, study and development of personnel in the fields of sciences and English language, and improper technology and administration for learning organization, all of which have affected the education system that need be changed in order to be able to respond to and face the aforementioned challenges.

Therefore, it is necessary for Thailand to reform learning process in order to build up the education system as the key mechanism for driving the country (Office of the Education Council, 2017). The reform of learning process will respond to changes in $21^{\text {st }}$ Century by modifying the learning system for $21^{\text {st }}$ Century by - developing the learning processes for all levels, iincorporating integrated learning systems that put more emphasis on practice and enable learners to control their own learning so that they can apply their knowledge to making money and have skills concerning careers and living. Furthermore, the system to produce and develop teachers has to be modified from the attraction, the selection of highly skilled candidates to be teachers, the promotion of the systems to continuously improve teachers' efficiency and competencies, covering the monthly wages, career paths and other supportive systems. All education management systems in all levels and of all types should be enhanced through the reform of the structures of educational organizations to be more efficient and the establishment of minimum standards for schools of all levels for higher learning achievements. The structure of education management need be improved to have more efficiency and to ensure improvement of education quality. Private sector should be encouraged to participate in education organization. The system of education quality assurance should be improved by separating education quality assurance from assessment, validation and supervision of the education quality. The examination system should also be reformed in order to test the skills necessary for $21^{\text {st }}$ Century rather than testing the level of knowledge. There should be the support and encouragement for research on and utilization of technologies for building and managing knowledge, learning and learning organization for developing career-related skills that concur with the contexts of each local area. There should be the development of lifelong learning by arranging education system and training system that is based on the competencies, with high quality and flexibility. There should be incentive to motivate and encourage people to learn and develop themselves, together with the improvement of career-related skills and the development of community learning system that is accessible anywhere and anytime from the collaborations from private sector, public sector and civil society. There should be the development of digital networking systems and technologies, and digital platforms for the education of all types and in all levels with full coverage and high efficiency, as well as the development of applied programs or digital learning materials with high quality that students and people can access and use for self-learning and development through modern technologies. Also, there should be the establishment of education system for international academic excellence to promote and enhance the capacities of educational institutes with expertise and uniqueness in terms of specific subjects to build the networks of international academic collaborations and exchanges among students and personnel in 
the international level. There should be the development of specific research centers and regional training and testing centers, and learning of history, traditions and culture of Thailand, and developments of neighboring provinces in terms of education systems for people. Children, youths and students should be encouraged to exchange knowledge and experiences with those from other Southeast Asian countries (National Strategic Plan Committee, 2018).

As for the aforementioned changes, education is an important tool in driving the progress of development of the country in all aspects, namely, economy, politic, society and culture. Therefore, it is imperative to promote and create conditions for continuous learning, and improvement of quality, efficiency and capabilities of the majority of people in the country, by adhering to the principles of networking whereby all sectors of society are allowed to participate in determining and making decisions concerning educational activities related to their organizations or agencies, in order to support the development of all sectors of society and at all levels, based on their own capacities, and to create the environment conducive to success, which will allow the development of the country with stability and sustainability.

Educational institutions are educational agencies and learning organizations that play important roles in knowledge management. Therefore, the roles must be adjusted to keep up with the changes in the surrounding society and the global society. Especially, the Royal Decree has set the principle that Government agencies have to develop knowledge Therefore, educational institutions must be developed in a new way of knowledge management. This means the performance of duties of administrators, teachers and other educational personnel who have knowledge and understanding, and can perform well in accordance with educational management directions. Furthermore, administrators of educational institutions must be effective reform leaders (Theera Runcharoen, 2016). Administrators can give academic advice or recommendations for both the development and implementation of educational institutions' curricula, learning organization, development and selection of learning materials, assessment and evaluation of learning outcomes, research for learning development and attention to educational arrangement by educational institutions, by monitoring, supervising, evaluating and implementing the findings from the evaluation to the continuous development or improvement in accordance with the mission with the best efforts and for all the work hours (Ministry of Education, 2016), so that education administration will be for efficient and effective.

However, the administration under the leadership of the Head of Department may cause difference in terms of the development of academic work among different departments. This may be because each Head of Department is a teacher of the school. Most of these heads still lack of experience and knowledge of academic administration. Thus, assuming the position, each head uses his/her own personal values and attitudes for administrating the department. This results in inefficient school administration. Also, most Heads of Departments are senior teachers or have greater skills than others. Assuming the position without prior training or preparation, these heads have no experience in academic administration. When taking the position, these heads must coordinate closely with the administrators and teachers. Therefore, broadly or roughly defined missions may not be very clear. The job nature that forces these heads to perform management tasks and academic coordination tasks with administrators and teachers forces these heads to respond to the policies and needs of people at both levels. With only few experiences, these heads may not be respected, and may not receive cooperation. Successful Heads of Departments often have specialized knowledge relating to their roles and can integrate leadership and management together in an appropriate ratio. The Head of Department therefore has to view himself/herself, as an instructor and an administrator; and has to combine the values that he/she upholds as an administrator with the values he/she upholds as a teacher, including the values and attitudes of as an operator, which should be implemented in to academic administration and management, in order to work effectively (Siriporn Saliwong, 2015). 
Functional competencies are behavioral characteristics that are specific to a particular work line or group that support or encourage state officials to have behaviors appropriate for their works and to perform their duties appropriately with maximum efficiency. The Head of Department position is an important position because of the roles that involve with many departments of the educational institutes. Therefore, it is necessary for such heads to have the knowledge and functional competencies of the Head of Department position.

Therefore, we, as researchers, are interested in studying on the components of functional competencies of the Heads of Departments of secondary schools under the Office of the Basic Education Commission in Thailand. The findings from the study can be implemented to the creation of the model for developing functional competencies of the Heads of Departments of secondary schools under the Office of the Basic Education Commission in Thailand. School administrators can implement the findings from the study to their actions. Educational agencies can apply the findings from the study to the development the functional competencies of the Heads of Departments of their schools. Likewise, the Office of the Basic Education Commission of Thailand can apply research findings to the formulation of a strategic framework for further development of the functional competencies of the Heads of Departments in the national scale.

\section{Methodology}

\subsection{Population and samples}

Populations of this research project are Heads of Departments of all secondary schools under the Office of the Basic Education Commission of Thailand, the total number of which is 18,864 heads from 2,358 schools.

Research samples are Heads of Departments of all secondary schools under the Office of the Basic Education Commission of Thailand. The sample size is 500, in accordance with criteria of Tabachnick and Fidell (2012) who stated that the sample size of 500 for factor analysis is considered very good because there is the dispersion of samples in the prorated manner with the populations.

\subsection{Variables}

The variables are synthesized in accordance with the studies of Marie Brown, Bill Boyle and Trudy Boyle (2002); Angela Choi Fung Tam (2010); Clive Smith, Raj Mestry and Alfred Bambie (2013); Kenneth Leithwood (2016); Teresa A. Oqina (2017); Phathara Saengphen and Direk Phonsema (2013); Office of the Basic Education Commission of Thailand (2013); Phinit Nambamrung (2017) and Nannaphat Bunyot (2018). After the synthesis of the 7 components of functional competencies of Heads of Departments of secondary schools under the Office of the Basic Education Commission of Thailand, through content analysis and survey on opinions of Heads of Departments. Such factors are known and retrieved from statistical analysis with Confirmatory Factor Analysis (CFA). The 7 compositions of functional competencies of Head of Department are 1) Intellectual Leadership 2) Quality Management 3) Educational Innovation and Information Technology 4) Professionalism Development 5) Curriculum, Measurement and Evaluation of Learning 6) Learning Organization and 7) Professional Ethic.

\subsection{Research tool}

The questionnaire used in this study has been designed and verified for its reliability, which is 0.91 . It consists of 64 questions relating to the 7 components as follows: 1) Intellectual Leadership 2) Quality Management 3) Educational Innovation and Information Technology 4) Professionalism Development 5) Curriculum, Measurement and Evaluation of Learning 6) Learning Organization and 7) Professional Ethic.

\subsection{Data collection}


The data are collected with the questionnaire distributed to the informants who are heads of department in schools of Basic Education Commission. Of all the handed out questionnaires, 495 (or 99\%) are returned. The returned questionnaires are reviewed for their completion. Afterwards, data from the questionnaires are processed and analyzed.

\subsection{Data analysis}

The confirmatory factor analysis technique is applied to the examination whether the theoretical data on which this study is based concur with empirical data or not. Confirmatory Factor Analysis (CFA) serves as a multivariate analysis for examining a concept that is based on multiple measured indicators (Fan, X. and Sivo, S., 2005). Estimation methods for CFA include a maximum likelihood factor that determines the optimal value of the loading of a factor. A factor is valid if its loading value on weighed standard regression is higher than 0.5 or $p .05$ ). In other words, $\chi 2$ /df is lower than 3.00 (Hair et al, 2010), RMR is inferior to 0.05 (Steiger, J. H., 2007), GFI is higher than 0.90 (Arbuckle, 1995), AGFI is greater than or equivalent to 0.90 (Arbuckle, 1995), and RMSEA is inferior to 0.05 (Goffin, R. D., 2007). This method consists of the Kaiser-Meyer-Olkin (KMO) test utilized to determine the suitability of data (0.85 = good) (Joreskog \& Sorbom, 1999), Bartlett's Test of Sphericity to measure the sampling adequacy $(11162.40, p$-Value $=0.71)$, Pearson's Correlation Coefficients test to identify the relationship between each pair of tested variables. Therefore, it can be affirmed that the test results will contribute to the accomplishment of the predetermined objectives. CFA has been examined to determine the validity of the model by LISREL 8.54. This analysis is carried out against the model, as well as each of the parameters included therein.

\section{Results}

Results from the test of the construct validity of the components of functional competencies of Heads of Departments from secondary schools under the Office of the Basic Education Commission of Thailand show that there are 7 observable variables that affect the results from CFA, as shown in Tables 1 and 2.

Table 1

Results from the Test of Correlation Coefficients Kaiser-Meyer-Olkin Measure of Sampling Adequacy: KMO and Bartlett's

Test of Sphericity of Observable Variables of Functional Competencies of Heads of Departments of Secondary Schools under Office of the Basic Education Commission of Thailand

\begin{tabular}{|c|c|c|c|c|c|c|c|}
\hline \multirow{2}{*}{ Variables } & \multicolumn{7}{|c|}{ Correlation Coefficients } \\
\hline & INL & QUA & IIT & PRO & CME & LEA & ETH \\
\hline Intellectual Leader (INL) & 1.00 & & & & & & \\
\hline Quality Management (QUA) & $0.45^{* *}$ & 1.00 & & & & & \\
\hline $\begin{array}{l}\text { Innovation and Information Technology for } \\
\text { Education (IIT) }\end{array}$ & $0.58 * *$ & $0.52 * *$ & 1.00 & & & & \\
\hline Professionalism Management (PRO) & $0.69 * *$ & $0.68 * *$ & $0.86 * *$ & 1.00 & & & \\
\hline Curriculum, Measurement and Evaluation (CME) & $0.63 * *$ & $0.64 * *$ & $0.79 * *$ & $0.89 * *$ & 1.00 & & \\
\hline Learning Organization (LEA) & $0.69 * *$ & $0.77^{* *}$ & $0.72 * *$ & $0.73 * *$ & $0.67 * *$ & 1.00 & \\
\hline Professional Ethic (ETH) & $0.61^{* *}$ & $0.71 * *$ & $0.71^{* *}$ & $0.72 * *$ & $0.62 * *$ & $0.63^{* *}$ & 1.00 \\
\hline $\begin{array}{l}\text { Kaiser-Meyer-Olkin m } \\
\text { Bartlett's Test of Spheric }\end{array}$ & $\begin{array}{l}\text { sure of s } \\
\text { : Chi-Squ }\end{array}$ & mpling a & $\begin{array}{l}\text { quacy: } \\
40 \mathrm{df}=\end{array}$ & $\begin{array}{l}0=0.85 \\
15 p=0\end{array}$ & & & \\
\hline
\end{tabular}

\footnotetext{
$* * \mathrm{p} \leq .01$
} 
Table 1 shows the correlation coefficients between the functional competencies of the Heads of Departments of secondary schools under the Office of the Basic Education Commission of all the 7 components. It has been found out that the correlation coefficients among the components range from $0.45-0.89$ and are statistically significant at the level of .01 for all pairs. The first three greatest coefficients descending order, are those between Professionalism Development (PRO) and Curriculum, Measure and Evaluation (CME) with the correlation coefficient of 0.89, Innovation and Information Technology (IIT) and Professionalism Development (PRO) with the correlation coefficient of 0.86 , and Innovation and Information Technology (IIT) and Curriculum, Measurement and Evaluation (CME) with the correlation coefficient of 0.79 , respectively. This indicates that the constituent variables have correlations greater than 0.30 for all variables and are consistent with the index analysis results. The value of Kaiser-Meyer-Olkin (KMO) is 0.85 , which is greater than 0.50 whilst the Bartlett's Test of Sphericity statistic has Chi-Square $=11162.40 \mathrm{df}=1515 \mathrm{p}=0.71$. It is apparent that this correlation matrix has differed statistically from the identity matrix at the 0.01 level.

There are sufficient correlations suitable for further CFA.

Table 2

Results from Confirmatory Factor Analysis (CFA) of Components of Functional Competencies of Heads of Departments of

Secondary Schools under Office of the Basic Education Commission of Thailand

\begin{tabular}{|l|c|c|c|c|}
\hline \multicolumn{1}{|c|}{ Variables } & b & S.E. & t & $\mathbf{R}^{2}$ \\
\hline Intellectual Leader (INL) & 0.79 & 0.03 & $10.58^{* *}$ & 0.56 \\
\hline Quality Management (QUA) & 0.78 & 0.04 & $4.15^{* *}$ & 0.55 \\
\hline Innovation and Information Technology for Education (IIT) & 0.89 & 0.03 & $8.75^{* *}$ & 0.64 \\
\hline Professionalism Management (PRO) & 0.84 & 0.03 & $2.91^{* *}$ & 0.56 \\
\hline Curriculum, Measurement and Evaluation (CME) & 0.88 & 0.04 & $19.03^{* *}$ & 0.59 \\
\hline Learning Organization (LEA) & 0.76 & 0.03 & $4.13^{* *}$ & 0.62 \\
\hline Professional Ethic (ETH) & 0.81 & 0.04 & $8.75^{* *}$ & 0.49 \\
\hline \multicolumn{2}{|c|}{$\chi 2=1484.85, \mathrm{df}=1515, \mathrm{p}=0.71, \mathrm{GFI}=0.93, \mathrm{AGFI}=0.93, \mathrm{RMSEA}=0.00, \mathrm{RMR}=0.04$} & \\
\hline
\end{tabular}

$* * p \leq .01$

The results from the CFA of the 7 components of functional competencies of the Heads of Departments of secondary schools under the Office of the Basic Education Commission show that the model is consistent with the empirical data, which can be determined from the Chi-square value of 1484.85 at the degree of freedom (df) of $1515 p=0.71$. The Root Mean Square Error of Approximation (RMSEA) is 0.00. The Root Mean Square Residual $(R M R)$ is 0.04 . The Goodness of Fit Index (GFI) is 0.93 and the Adjusted Goodness of Fit Index (AGFI) is 0.93. These results reflect that the functional competencies of the Heads of Departments of secondary schools under the Office of the Basic Education Commission consists of 7 components from 64 variables. The results of CFA of the functional competencies of the Heads of Departments of secondary schools under the Office of the Basic Education Commission, compared with empirical data, show that it consists of 7 components out of 64 variables as shown in Figure 1. 
Figure 1

Model from Confirmatory Factor Analysis of Components

of Functional Competencies of the Heads of Departments of secondary schools under the Office of the Basic

Education Commission

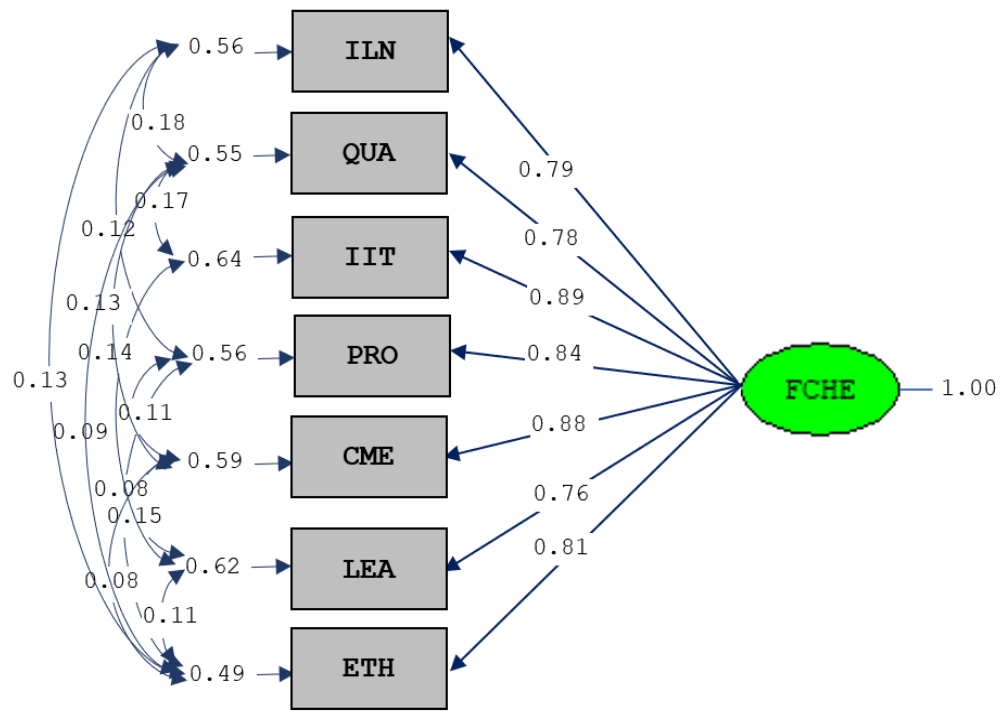

Chi-Square $=1484.85, \mathrm{df}=1515, \mathrm{P}$-value $=0.70513, \mathrm{RMSEA}=0.000$

\section{Discussions}

Findings from the CFA reveal that the seven functional competencies of the Heads of Departments in Thailand have been proven to be necessary for a qualified Head of Department through the validation of the model. The 7 components of functional competencies test of Head of Department can be aligned with the level importance as follows: Educational Innovation and Information Technology $=0.89$, Curriculum, Measurement and Evaluation $=0.88$, Professionalism Development $=0.84$, Professional Ethic $=0.81$, Intellectual Leadership $=0.79$, Quality Management $=0.78$ and Learning Organization $=0.76$, respectively.

From the weights of the components of functional competencies of the Head of Department of the secondary school under the Office of the Basic Education Commission in Thailand, it is discovered that Innovation and Information Technology Component has the highest weight (Factor loading $=0.96$ ), indicating that the Heads of Departments of the secondary school under the Office of the Basic Education Commission in Thailand emphasize on innovations and technologies because in the modern era, the world is constantly evolving. In addition, one has to learn all the time,. Therefore, Heads of Departments feel that the component of Innovation and IT is of the greatest importance. This concurs with the explanation by Seehamat, C. \& Viriyavejakul, C. (2019) that education-related innovations and technologies constitute important foundation leading AEC to enjoy the flourishing economy of ASEAN and the world. Furthermore, educational businesses in ASEAN have become grand and boundless, which can be seen as educational freedom in ASEAN and the world. This phenomenon can lead to serious competitions in education management. Development of innovations and technologies for education in AEC would affect the development of educational standards of ASEAN to be internationally comparable with those in European countries and the United States of America. All the aforementioned things happen in order to meet the changes and the needs of high-quality human resources of national and regional labor markets. Such development can set up guidelines that lead to academic collaborations among public and private educational institutions. Aigul N. G., Berik B. S., Razida Z. G., Assem T. M. \& Saltanat I. T. (2018) have explained that the 
creation of high, knowledge-intensive technologies can happen where there are accumulation and mobilization of intellectual capital of science and education institutions. As such, a fairly important part is assigned to a higher school in this process. An emphasis on high, knowledge-intensive technologies, which is tremendously important to the progress as a whole, means the highest priority is given to the task of integrating science and higher education during innovative development. An education system must create graduates with high quality, especially in the framework of the system of higher vocational education. In order to improve the quality of human resource development and the integration of educational service market into the labour market of high demand, it is necessary to choose an innovation-oriented path of education system development, which will allow the orientation of the modern system of higher education to a scientific and technological system of the training and retraining of staff rather than to educational activities. Information and scientific-research environment has led to creative activities of higher educational institutions. Integration of a higher education institutes with the scientific and technical space must be organized and stimulated with the establishment of innovative policies and the development of a set of measures for the higher education system. Thus, these processes of integration must serve as a basis for the formation of the tactics and the strategy of innovative development of the education system in the Republic of Kazakhstan. Larysa A. S., Karyna Y. S., Alina A. M. \& Ruslan A. P. (2018) have explained that an innovation is specific and very complex, demanding special knowledge, skills, and abilities. Innovation cannot take place without pedagogical diagnosis by teachers at high schools, who have systematic thinking, and developed abilities to be creative, and to form conscious commitment to innovation. We see our further works that will lead to the development of media technologies for the quality of higher educations of students.

Boonkua A., Tuntinakorngul A., \& Tingkunanan P. (2019) have explained that innovation organizations of basic education institutions in Thailand can be considered as a way of the development of educational arrangement for improving the management process to become sustainable. If an educational institution has administrators with appropriate leadership, and atmosphere conducive to the generation of innovation, with teachers and educational personnel applying innovation to teaching and learning, and students having innovative thinking skills, educational institutions will be developed as innovative organizations that can continually create innovations. This leads to the readiness for competitions and creates value for educational management in terms of cost-effectiveness and achievement of the quality in accordance with the criteria that aim at sustainable efficiency and effectiveness.

From the study on the components of functional competencies of Heads of Departments of secondary schools in Thailand, it can be concluded as follows. Educational institutions that can develop their Heads of Departments to have functional competencies must pay attention to all the aforementioned components. In addition, the findings from this research have confirmed that components of functional competencies of Heads of Departments of the secondary school level under the Office of the Basic Education Commission in Thailand, include Curriculum, Measurement and Evaluation, Professionalism Development, Intellectual Leadership, Professional Ethic, Learning Organization and Quality Management. These components are included in the model for functional competencies of the Heads of Departments of secondary schools under the Office of the Basic Education Commission in Thailand, which has been developed on the bases of the findings from the study.

\section{Conclusions}

From an overview of secondary schools under the Office of the Basic Education Commission in Thailand, things that are important and necessary for the development of functional competencies of the Heads of Departments of secondary schools in Thailand are the components of the model, which are essential for the planning and development of the quality of Heads of Departments in the sustainable way. 


\section{Bibliographic references}

Aigul, N.G.; Berik, B.S.; Razida, Z.G.; Assem, T.M., \& Saltanat, I.T. (2018). Application of innovative technologies at higher school: experience and prospects of the Republic of Kazakhstan. Revista Espacios. 39 (49), p.27.

Angela Choi Fung Tam. (2010). Understanding the leadership qualities of a head of department coping with curriculum changes in a Hong Kong secondary school. School Leadership \& Management. 30(4), 367-386 Arbuckle, J.J. (1995). AMOS user's guide. Chicago: SmallWaters.

Boonkua, A.; Tuntinakorngul, A., \& Tingkunanan, P. (2019). A confirm factor analysis of innovative organization in basic education institutions: A case study in Thailand. Revista Espacios. 40 (44), 14.

Brown, M.; Boyle, B., \& Boyle, T. (2002). Professional development and management training needs for heads of department in UK secondary schools. Journal of Educational Administration. 40(1), 31-43.

Fan, X., \& Sivo, S. (2005). Sensitivity of fit indexes to mis specified structural or measurement model components: Rationale of two-index strategy revisited. Structural Equation Modeling. 12(3), 343-367.

Goffin, R.D. (2007). Assessing the adequacy of structural equation model: Golden rules and editorial policy. Personality and Individual Differences. 42, 831-839.

Hair, et al. (2010). Multivariate data analysis. $4^{\text {th }}$ ed. New Jersey: Pearson Education International.

Joreskog, K.G.; Sorbom, D.; Du Toit, S., \& Du Toit, M. (1999). LISREL 8: New statistical features. Chicago: Scientific Software International, 6-7.

Kenneth Leithwood. (2016). Department-Head Leadership for School Improvement. Leadership and Policy in Schools. 15(2), 117-140.

Larysa, A.S.; Karyna, Y.S.; Alina, A.M., \& Ruslan, A.P. (2018). Innovative technologies of pedagogical diagnostics as a means of improving the quality of future specialists'education. Revista Espacios. 39(49), 20.

Ministry of Education. (2016). Education Development Plan of the Ministry of Education No. 12. Bangkok: Office of Policy and Strategy Office of the Permanent Secretary, Ministry of Education Ministry of Education.

Nannaphat Bunyot. (2018). Development of a curriculum to enhance academic leadership for heads of learning subject groups in educational institutions under local government organizations. Krupibul Journal. 6(1), 134-150.

National Strategic Plan Committee. (2018) National strategy 2018-2037. Bangkok: Office of the Secretary of the National Strategy Board Office of the National Economic and Social Development Board.

Office of the Basic Education Commission. (2013). School Management Manual in the Juristic Person Management Development Project. Bangkok: Agricultural Cooperative Association of Thailand.

Office of the Education Council. (2017). National Education Plan 2017-2036. Bangkok: Sweet pepper graphics.

Phat Saengpheng \& Direk Phonsima. (2013). Transformational Leadership Empowerment Model Academic Teacher Head of Department High School under the Office of the Basic Education Commission. Academic Journal of Eastern Asia University. 3(2), 57-70. 
Phinit Nambamrung. (2017). Development of a competency training course for the subject group leader in secondary schools Under the Office of Secondary Education Service Area, Region 20. Praewa Kalasin Academic Journal Kalasin University. 4(3), 454-472.

Seehamat, C., \& Viriyavejakul, C. (2019). Future vision of educational innovation and technology for ASEAN community. Revista Espacios. 40(17), 15.

Siriporn Saliwong. (2015). Development of character indicators that facilitate participatory management of the subject group leader. in schools affiliated with Bangkok. Doctorate of Education Department of Educational Administration. Graduate School, Srinakharinwirot University.

Steiger, J. H. (2007). Understanding the limitation of global fit assessment in structural equation modeling. Personality and Individual Differences. 42, 893-898.

Teresa, A. Oqina. (2017). How heads of Departments Understand Their Roles as Instructional Leaders: A South African Study. International Journal of Educational Sciences. 18(1), 224-230.

Theera Runcharoen. (2016). Professionalism of educational institution administrators, problems, necessities and practices. Bangkok: Khao Fang. Attribución-NoCommercial 4.0 International

\section{(cc) EY-NC}

